\title{
XLI. Examination of the red coloured water of a lake near Lubotin, in South Prussia
}

\section{Professor Klaproth}

To cite this article: Professor Klaproth (1803) XLI. Examination of the red coloured water of a lake near Lubotin, in South Prussia, Philosophical Magazine Series 1, 17:67, 243-250, DOI: $10.1080 / 14786440308676407$

To link to this article: http://dx.doi.org/10.1080/14786440308676407

册 Published online: 18 May 2009.

Submit your article to this journal $₫$

Џll Article views: 2

Q View related articles 5 
Red coloured Water of a Lake in South Prussia. 243

\author{
$1 \frac{1}{4}$ oxide of iron \\ $\frac{1}{2}$ oxide of manganese. \\ Analysis of the Pearl-stone of Hungary:
}

The mountains of Tekelbart in Hungary, from which so many rare fossils are extracted, among which are the beautiful changing opals, furnish that also which Werner has classed in the system next to Pitch-stone, under the name of Pearl-stone.

That which M. Klaproth subjected to analysis is of an ash gray colour, traversed by yellow bands. It is found between Kerestur and Tokai, in alternate strata separated by others of argillaceous porphyry.

The specific gravity of this fossil is 2340. It swells up by the blowpipe like zeolite; but it does not fuse into a globule.

A picce calcined for two hours in a moderate fire lost nothing of its form. Its colour had become reddish brown. It had experienced $\frac{1}{2}$ per cent. loss.

Pearl-stone was completely vitrified in a porcelain furnace in a clay crucible, as well as in a crucible lined with charcoal.

A hundred parts of the pearl-storie of Hungary, treated successively by soda and by acids, gave in their analysis:

\begin{tabular}{llll} 
Silex & - & - & $75 \cdot 25$ \\
Alumine - & - & - & 12 \\
Oxide of iron & - & - & 1.60 \\
Lime - & - & - & 0.50 \\
Potash & - & - & 4.50 \\
Water & - & - & 4.50 \\
\hline & & & 98.35
\end{tabular}

[To be continucd.]

XII. Examination of the Red coloured Water of a Lake near Labotin, in South Prussia. By Professor Kiaphoth*.

I

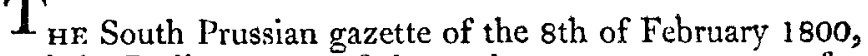
and the Berlin gazette of the 13th, gave an account of $a$ phænumenon

* From Scherer's Allgemeines Fournal der Cbemie, No. 33-About twenty years ago Mr. Achard examined water tinged in a similar manner, whicl he obrained from a lake near Strautzberg. In the month of December, 1737 , the ice of this lake was coloured red, and continued so till the Q. month 
phænomenon observed in the water of a lake near the village of Lubotin, in the department of Poren in South Prussia. The most remarkable particulars of which were as follows:

The water of this lake had appeared for some time to be covered with red spots, like drops of blood : in other places of considerable extent it was of a violet red colour; in others of a grass green colour, and large masses of a red matter floated on the surface of it. When the lake in eonsecquense of the severe cold became frozen, the ice for three lines in thickness was of the same red, blue, and green colour which the water had exhibited. The lower part of the jce, bowever, was uncoloured: a green and red matter inclining to blue was found below the ice to the thickness of a quarter of a yard.

A manuscript account of the same phænomenon gives the following account;-About the middle of December the fishermen, on breaking up the ice in order to fish, observed that not oply the ice but also the water of the lake was coloured red, blue, and green, in two places. The lake is about a quarter of a mile in length, four hundred paces in breadth, and is completely surrounded by mountains.

A wood stands close to the margin of the lake on one side, and on the other lies the village of Lubotin with its surrounding district: an arm of the lake, about a hundred feet in length and a few paces in breadth, extends to the village. In this arm, and for a certain extent on both banks of the lake, the water was coloured to half an ell in depth; but under this coloured stratum the water was in its usual state. The case was the same in a part at the extremity of the lake, about fifty feet in length and twelve or thirteen feet in breadth. The water in the remaining part of the lake was colourless. The ice which covered these places was marbled with green, blue, and red spots, of from one to two feet in length. The lower part of the ice, like the water below it, had no unusual colour.

Both these accounts coincide in regard to the principal points of the phænomenon; the small deviations arise no

month of March, when it appeared to be geen. In the latter state the water could be used for painting. The red water, afrer it had stood for some time, deposited a red insipid matter, which, when viewed by the microscope, seemed to be composed of threads interwoven with each other. Mr. Achard concluded, from the few experiments he made with it, that the colouring matter was a vegretable substance. See his Cby. miscb Physisibe Scbrificn, Berlin 1780, P. $251-253$. 
doubi from the observations having been made at different times.

It may readily be believed that superstition, as usual, converted this natural phænomenon into a wonderful pradigy, which was considered as the consequence of a shower of blood, and the forerunner of various misfortunes.

To the enlightened philosopher, however, such phænomena are of importance, as they afford him means of explaining, on true principles, what few men of science have made an object of their research.

It needs, therefore, excite no wonder that different opinions have been entertained in regard to the nature and cause of this phrnomenon. Some ascribed it to mineral substances, and thence deduced proofs of the existence of veins of ore concealed in the neighbourhoot. Others con ceived that it had some connection with the earthquake which had a little before been experienced in several parts of Silesia and Bohemia. But, by the help of chemistry, this phænomenon has been found susceptible of another explanation much simpler.

Various authors, both antient and modern, speak of water being coloured and altered in its appearance: Wo are told by Pliny * that the water of the lakes near Babylon had a red colour for eleven days in summer, and that the Borysthenes, now called the Dnieper, was in summer of a blue colour. In $1668 \mathrm{Mr}$. Smith $\uparrow$ found the water of the Mediterranean to be of a sky blue colour, and when the sun shone upon it this colour was changed to red or purple. The missionary Ferdinand Consag $t$, in the year 1746, observed in the open sea, near California, that the water for the extent of half a mile was of a bluish red colour. Navigators have often seen the water at the mouth of the river Plata, on the coast of South America, of a blood red colour. Schooten found the water at Cape Desire coloured red, in consequence of a sea unicorn (Monodon Monoceros) having lost its horn.

Water is sometimes coloured red, not in reality, but apparently by aquatic insects, which at certain seasons cover the surface of ditches and ponds.

The present case, however, is different. The coloured water of the lake near Lubotin, a considerable quantity of which was sent to Berlin for chemical examination, excited great attention when first seen, by its agreeable change-

$$
\text { *IIist. Nat. lib. xxxi. cap. } 3 \text { a. }
$$
\$ Hist. de Califurnic, tom. iii. Paris $\$ 767$. 
ableness of colour. When viewed in a vessel of white glass and turned from the light, it appeared of a dark red colour, inclining to crimson, which rendered it entirely opake; but the froth with which it became covered on being strongly shaken was of a bright blue colour. When the glass was turned towards the light the redness vanished, and the water appeared of a sky blue colour. This change of colour took place for several days when the water was preserved in a close vessel.

The results of the different researches made in regard to this phrnomenon were as follows:

1st. White paper which had been immersed in this water appeared, after being dried, of a blue colour. The colour suffered no perceptible change either from diluted acids or from alkaline salts.

2d. When poured into a porcelain saucer the water appeared red in the middle and blue at the edges. When placed on warm sand indigo-blue rings were deposited on the sides of the vessel during the evaporation: the last portion, however, was dried into a dirty blueish green mass. When put into-water it was not redissolved, but merely divided into blackish scales. The water was again evaporated and digested, but the flakes still remained insoluble.

$3 \mathrm{~d}$. Another part of the water was put into a glass vessel closed only slightly and deposited in a warm place. The water soon lost its colour, assumed a caseous appearance, and deposited tender blueish green flakes, which were collected and dried. When put on ardent coals, or held to the flame on the point of a knife, they puffed up and burned, emitting the smell of burnt animal substances.

4th. When mixed with alcohol the mixture gradually became turbid, and slimy bheish flakes were separated.

5th. By the addition of sulphuric acid the water, as soon as the first drop of acid fell into it, lost the property of becoming red even when turned from the light, and appeared when held in every direction of a bright blue colour. When exposed to heat, the water at first appearcd of a light green colour; it then became completely colourcd, and tender woolly thready flakes of a blue colour were deposited.

6 th. When decomposed with sulphuric acid the colour of the wa er first became of a bright grass green colcur, then of a lemon, and at last of a straw colour. The tender woolly flakes were of a dirty grayish green colour.

7 th. When the water was decomposed with pure nitric acid it appeared throughout of a sky blue colour. When exposed to heat all the colour disappeared, the water not 
only becaine perfectly clear and colourless, but the caseous flakes which were separated appeared of a pale whitish yellow.

8th. Oxygenated muriatic acid destroyed the colour completely in the course of a few seconds. The water remained for some time turbid and whitish: when exposed to heat it suffered ycllowish flakes to be deposited.

9th. By caustic alkali the colour of the water immediately became brownish. A few gray flakes were deposited; the greater part of which, however, were afterwards dissolved. When the clear solution was neutralized by muriatic acid, the part dissolved in the alkali was again separated in soft yellowish gray flakes.

These results are sufficient to enable chemists to determine with certainty the nature of the matter contained in this water. It consists of those component parts commonly comprehended under the name of the albuminous principle, and which in the present case served as the basis of a peculiar colouring matter of the nature of indigo. This vegetable albumen which is contained in a great many plants, and to which belong those component parts of vegetables known under the names of gluten, materia vegetoanimalis, \&c., is, in regard to its component parts and chemical properties, of an animal nature, and has a near affinity to animal albumen, the caseous parts of milk, and the curdled part of serum. If those plants which among their intimate component parts contain this albuminous matter are abundant at the same timc in colouring matter, the latter is commonly in ciose union with the former. We have an example of this in indigo, the basis of which is of the same nature as albumen.

The dispersion in water of this colouring matter, combined with albumen, can take place only at periods when the plants, to the component parts of which it belongs, are in a state of solution and decomposition by desiccation or putrefaction. The phænomenon, therefore, cannot be observed in summer, when the plants are alive and in a state of vegetation, but only in winter, when they are dead. By the successive decomposition of the dead plants under the water, the extractive matter, and such of its componcnt parts as are susceptible of complete solution in that fluid, pass into it. The albumen is at first received by the water, but it does not enter into a constant, but only apparent and mechanical, solution; the particles exercise a mutual attraction, approach each other, and in that state form a flaky accumulation which floats on the water till 
they at length are converted into a sort of slime. The colouring mattcr combined with the albumen undergoes. also essential changes, till, being gradually overloaded with. oxygen, it is entirely decomposed. When left to itself in stagnant water this disappearance of the colouring matter takes place only very slowly. The coloration of the water by it may therefore, especially in winter, continue several weeks. On the other band, when a speedier saturation with oxygen is effected the colour is immediately decomposed, as is the case when the coloured water is decomposed by nitrous acid or oxygenated muriatic acid.

Nothing further, therefore, seems necessary to explain this phænomenon than a botanical determination of those plants which after their death transmit these component parts to water. This task, however, I must leave to botanists who may have an opportunity of making such researches on the spot. But I must here observe, that a season of the year in which one can hope to find these plants in their living state ought to be chosen for this purpose.

From various grounds, however, it appears to me probable that these plants belong to the order of the cryptogamia aquatic plants, and are perhaps of the spccies of the Conferva tremella, Utva, \&c. Albumen seems to form a principal component part in these plants, because on their decomposition in the dry way, besides the usual products, they give also ammonia. It inight therefore be of importance to examine whether this colouring matter, which manifests itself by the natural decomposition of the plant, could be extracted from it immediately by artificial means. I am inclined to think that this matter will be found in the Uh/a pruniformis, Linn., bccause this singular plant, at the end of its regetable life, is converted into a gelatinous substance, and in that state, before its total solution, floats for some time on the surface of the water. The phænomena I nksorved in my experiments on this coloured water exhibited a chemical analogy to those of the colouring matter obtained lrom the indigo phant, lndignfera tinctom ria; Ind. araentia; Ind. disperma; and from woad, Isatis tinctoria. For thengh the water appeared of a dark red crimson colmur, this colour was merely an optical illusion, accasioned by the refraction of the rays of light. The real colour was a pure blue. This property of indigo matter to sssume an apparent red colour I have observed in the snlid colouring matter itself, as the best sort of the West Indian indigon, as well as that extracted from woad, ex- 
hibits on its smooth surface, when exposed to the hight, a cupreous colour. The phænomenon also observed in regard to indigo, that when strewed over coals the smoke which rises immediately from it, when viewed against the hight, has a beautiful light red colour, may be connected with the same causes.

This phænomenon is not so uncommon as seems generally to be believed. A few years ago I had an opportunity of making similar experiments on water found in a lake at Strautzberg, not far from Berlin. The same circumstances were observed here, and in the same season, namely, the winter. The water of the lake was in some places coloured red, blue, and green; and masses of the same colours floated about in the parts of the water which were colourless. In flasks which were filled with the water and transmitted to me, the coloured part of the water gradually separated itself and ascended, while the water at the bottom remained colourless. The phænomena which took place in the course of my experiments were exactly similar to those which occurred in my researches respecting that of the lake near Lubotin. In January 1799 Mr. Achard had an opportunity to subject the water of this lake, supposed to be converted into blood, to some experiments also, from which he concluded that the colouring matter consisted of some vegetable substance, and floated in the water but was not properly dissolved in it. The small quantity which he had obtained of this water did not permit him to make any further experiments of a more decisive nature.

A similar phænomenon had been before observed several times in the lake near Strautzberg. According to an account published by Mr. Campe, a clergyman at Alt-Landsberg, in the Physicalischen Belustigungen*, he saw in the year 1737 the water of that arm of the lake which proceeds towards the town entirely of a red colour. Fifteen years after, the lake in the same place appeared to be wholly green. In the course of two days the water had resumed its usual colour. The water put into flasks, which at first was somewhat red, gradually became putrid; soon after it was thick and muddy; and at the end of some weeks there was separated from it a dark red mass which floated on the surface. In the present case it appeared of two colours: when turned from the light, opake and dark red; when turned towards the light, dark green. This green colour observed by Campe is, however, not essentially different. 
from the blue colour of the water which I examined: it only shows that the proportion of the oxygen combined with the colouring matter was less. For when that quantity of oxygen, which converted the original green colour of the water of the lake of Lubotin into blue, was extracted by means of borlies which had a greater affinity for oxygen, the green colour returned; as twas the case when the water was decomposed with sulphuric acid, or with a solution of tin in muriatic acid.

A similar return of blue to green is observed in indigo when employed in the art of dyeing. To prepare it for that purpose it must be decomposed with such substances as deprive it of a part of its oxygen. The prepared indigo liquor appears then green, and the cloth dipped in it is taken out green. But while the cloth is spread out in the air the pigment has an opportunity of acquiring that oxygen which it lost in the bath, by which means the blue co. lour is produced and fixerl.

This coincidence in regard to the phænomena observed in the water of the lake of Lubotin with those of indigo, affords a further proof that the colouring matter of that water was of a nature analogous to indigo.

XLII. Explanation of the Inscription on a Brick from the Site of antient Babylon. By the Rev. Samuer HeNLEY, M.A.F.A.S.*

$\mathrm{O}_{\mathrm{N}}$ the face of Dr. Hulme's brick, over two rude figures of a large dog, burking, and the head of a water-lird, is the following inscription:

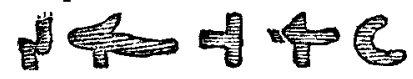

which, expressed in Hebrew characters, distinctly exhibits the words is 1 , and literally signifies, A BRICK BAKED BY THE SUN.

That $\rightarrow C$ עa, in its primary sense, placenta cocta (Simonis Lexicon, by Eichhorn) is a baked lrick, it is presumed no one will question; any more than that $\$<$ iN, signifies the sun; when the ground for so rendering it is given.

That is was the name of an antient city in Egypt, styled

* From Archarelogia, or Miscellaneous Tracts relating to Antiquity, by the Society of Antiguaries, - just published. 